\title{
Prevention of Miscarriage of Justice in the Implementation of Judges' Tasks
}

\author{
Tetania Retno Gumilang and Victoria Tabita Majesty Lamada \\ Faculty of Law, Tarumanagara University, Jakarta-Indonesia \\ gumilangteta@gmail.com and victoriatabitha31@gmail.com
}

\begin{tabular}{|c|c|}
\hline & Published: 15/09/2020 \\
\hline How to cite (in APA style): & \\
\hline
\end{tabular}

\begin{abstract}
Work by relying on conscience, to decide whether someone is guilty or not. The judge profession is one of the noble professions. The judge determines a person's actions. Judges are called noble, clearly addressing this profession has a higher degree. In convicting a criminal, besides at least two valid evidence, a judge's conviction is needed. The judge is called the representative of God on earth. However, judges are still ordinary people who are not free from mistakes. Miscarriage of justice happens a lot in the decisions they make. This study examines the prevention of miscarriage of justice in the implementation of judges' tasks. This research is designed by using normativejuridical method, which is an approach that uses a positivist-juridical conception, namely that law is identical with written norms created by the authorities, so far the law is made as a normative system that is autonomous closed and independent of people's lives. The results show that Justice is something aspired by the people of Indonesia. Judges are the most important element in realizing justice that is highly aspired. Judges as representatives of God who hold to the "For the sake of justice based on the Almighty God" develop a difficult task. Many miscarriage of justice occurs in the community. Judges as a profession that has a higher degree must hold on to professional ethics to avoid miscarriage of justice.
\end{abstract}

Keyword: Judge; Miscarriage of justice

\section{INTRODUCTION}

As a developing country, Indonesia is incessantly conducting development in various fields. One of the developments is in the field of law following the provisions contained in the 1945 Constitution that Indonesia is a state of law. Along with the development of development in the field of law, also developing problems in the field of law. Problems in the field of law cannot be solved by being left alone, a way to combat the problems in the field of law with illicit law enforcement. The purpose of law enforcement is the regulation of a peaceful life (Vrede, peace) which must be maintained through the process of law enforcement. Mertokusumo (2018) teaches 3 (three) theories about the purpose of law enforcement, namely: ethical theory that emphasizes aspects of justice, utility theory that aims to guarantee the greatest happiness for humans in as many numbers as possible (the greatest good of the greatest number), and mixed theories that requires the "order of order" which is a basic requirement for the existence of an organized human society for the attainment of justice that varies in content and size according to the community and its era. The following description are the latest research related to the current issue. Firstly, Cooley \& Turvey (2014) said that professional accountability represents the best way for preventing miscarriages of justice. Furthermore, Gill (2016); Greenwood \& Eady (2019); Lee, (2020); Nobles \& Schiff (1995) discussed about how police policies and practices impact successful crime investigation. It was shown that "crime control-oriented" policies were effective while 
"due process-oriented" policies were ineffective in clearing cases; some were even significantly counterproductive. The last, (Elks, 2008:29) revealed that the Commission's central role is to identify and refer convictions which raise a 'real possibility' that they would be quashed if referred for appeal.

In law enforcement there are certainly state institutions that carry out the task of realizing justice aspired to all Indonesian people including the Constitutional Court (MK), the Supreme Court (MA), the Indonesian National Police (Polri), the Attorney General's Office, the National Human Rights Commission (Komnas HAM), etc. An independent, neutral (competent), competent, transparent, accountable and authoritative court that can uphold the authority of the law, legal protection, legal certainty, and justice is a condition sine quan non or an absolute requirement in a state based on law. For the sake of the rule of law, the judge has a very important position and role. According to Article 1 of Law No. 8 of 1981 concerning the Criminal Procedure Code, a judge is a state justice official who is authorized by the law to try. Then according to article 1 paragraph (5) of Law No. 48 of 2009 concerning Judicial Power, stipulates that what is meant by judges is "Judges in the Supreme Court and judges in the judiciary below it within the scope of general courts, religious courts, military courts, state administrative courts, and judges in special courts located in the judicial environment ". The constitutional judge is a judge at the Constitutional Court. An ad hoc judge is a judge who is temporary and has the expertise and experience in a particular field to examine, hear, and also send a case whose appointment is regulated in law.

Judges, which are types of work that, among others, demand certain education and skills in carrying out their duties, certainly requires professional ethics. Because every human being whoever and whatever profession requires contemplation of morality associated with the profession. Etymologically, the term "ethics" comes from Ancient Greek, ethos. Ethics is included in the area of values, while the ethical value itself is related to the good and bad actions of humans. Judges in carrying out their duties have a separate code of conduct that is regulated in a Joint Decree of the Chief Justice of the Republic of Indonesia and the Chairperson of the Republic of Indonesia Judicial Commission Number: 047 / KMA / SKB / IV / 2009 and 02 / SKB / P.KY / IV / 2009 concerning the Code of Ethics and Conduct Judge. But the fact is the purpose of law enforcement, namely justice and legal certainty, is often not achieved due to inconsistencies in law enforcement efforts carried out by the judge's duties. This phenomenon is commonly referred to as miscarriage of justice or failure to achieve justice. We are as candidates for law enforcement officials, especially candidates for judges, certainly do not want justice, which is what aspired by the Indonesian people to not be achieved. Thus, this study aims to discuss about prevention of miscarriage of justice in the implementation of judges' tasks.

\section{METHOD}

This research is designed by using normative-juridical method, which is an approach that uses a positivist-juridical conception, namely that law is identical with written norms created by the authorities, so far the law is made as a normative system that is autonomous closed and independent of people's lives. The research specification used in this study is descriptive-analysis, which is a study that describes the applicable formulation of legislation assembled with positive legal theories concerning the matter being examined.

In connection with the method used in this study is the normative-juridical approach, the data source used is secondary data. The secondary data sources referred to include the applicable formulation of legislation, literature books, documents or archives relating to the subject matter written. The data obtained were analyzed in a qualitative normative way which is to describe and interpret the data based on the principles, norms, theories / doctrines of law. After analysing the data, then presented in the form of a description arranged systematically, logically, and rationally. In the sense that the overall data obtained will be linked to one another and adjusted to the main points of the problem so that it is a unified whole with the subject matter under study. 


\section{DISCUSSION}

Before the amendment to the 1945 Constitution it was written that "Indonesia is a state based on a rule of law", but after the amendment to the 1945 Constitution the sentence changed to "The State of Indonesia is a rule of law". The sentence is contained in Article 1 paragraph 3 of the 1945 Constitution which although the sentence changes the point remains the same, namely to make Indonesia a constitutional state. Understanding the rule of law according to Attamimi (1992), the rule of law (rechstaat) is simply a state that places the law as the basis of state power and the implementation of that power in all its forms is carried out under the rule of law.

The rule of law is a country that stands on the law that guarantees justice to its citizens. Justice is a prerequisite for the achievement of happiness or welfare of life for citizens and from that justice needs to be taught morality to every human being so that he becomes a good citizen. Indonesia itself adheres to the concept of a rule of law based on Pancasila, which is the basis of the state Pancasila as stipulated in the Preamble to the 1945 Constitution.

In the process of seeking justice, Aristoteles proposed 2 (two) theories of justice, namely distributive justice, namely justice that gives each person a ration according to service (comparability) and commutative justice, namely justice that gives to every person the same amount, with no memory for services. Personal services (this theory is more aimed at legal or state relations with its citizens). Concerning these two theories, Aristotle argues that law must determine general rules, and justice demands that each case must be weighed separately. Jhon Rawls through the book A Theory of Justice said that there are 2 principles of justice: everyone must have the same rights to the basic freedoms which are very broad in accordance with the same freedoms for others and social and economic mismatches must be regulated so that they can be expected to benefit all and strengthened by open positions for all. Justice itself is found in the process of law enforcement. Every Indonesian citizen has his expectations related to law enforcement that protects each individual. At the level of concepts and theories, law enforcement that provides protection for each individual is ideal and is mandatory to be implemented, but at the level of application, the law is not sufficient to protect justice seekers (justitiabelen), especially those relating to justice, legal certainty, equality in before the law, and the fulfilment of their human rights.

Referring to the law enforcement process it is certainly not far from the name of a state institution that has the task of seeking justice. One of the professions assigned in the creation of the law enforcement process is the role of the judges' profession in it. Various aspects of the purpose of the establishment of concrete legal regulations will equip judges to provide fair legal considerations following the legal justice implied in the systematics of the Law on which they are based. Judges are one of the basic and main bases in upholding law and justice that are commonly referred to as an extension of God.

When a judge is handling a case, it is expected to be able to act wisely and wisely, uphold the values of justice and material truth, be active and dynamic, be based on positive legal instruments, make logical reasoning in accordance and in harmony with theory and practice so that all lead to decisions that are it will be dropped which can be accounted for from the aspect of legal science itself, the rights of the accused, the community and the state, themselves, and for the sake of justice based on the Godhead. Because carrying out such a heavy task, for that, it must be guaranteed independence to uphold the joints of justice as byword, "even though the sky collapses justice must be upheld". Whereas on the other hand, the judge is also required to have good moral integrity so that in upholding the law and justice other issues are not easily affected, such as being tempted by collusion, bribery, and others which can ultimately harm justiabelen.

Judges have a very important position and role, for the sake of the rule of law. The issue of judicial power is specifically regulated in Article 24 and Article 25 of the 1945 Constitution. The explanations in both articles emphasize that judicial power is an independent power, meaning that it is independent of anyone's influence. Judges occupy different positions in various legal systems. Nevertheless, it was agreed that the judge was the main interpreter of general legal norms in the concrete events that took place. A judge 
must focus on exploring justice and must be able to overcome all obstacles and obstacles that occur in the process of seeking justice.

In essence, a judge is expected to consider whether someone is wrong or not whether a dispute is true or not, then gives a legal determination. Judges are obliged to avoid mistakes in making decisions or ignore facts that can ensnare the accused or the parties or deliberately make considerations that benefit the defendant or the parties in trying a case he is handling. The outcome in a case is very dependent on the considerations issued by the judge included in the decision. Duties and functions of judges are not always to decide, the most important function of judges in resolving legal issues is by giving peace to the parties seeking justice, as the provisions in Article $130 \mathrm{HIR} / 154$ $\mathrm{RBg}$ require the judges to reconcile the parties litigate in a civil dispute.

According to Mertokusumo (2018), legal certainty aims to provide legal protection to the judiciary against arbitrary actions. Meanwhile, the public expects legal certainty, because with legal certainty the community will be more orderly. The law is in charge of creating legal certainty because it aims at legal order. At the same time, in law enforcement and law enforcement, judges must be able to realize justice. If there are statutory provisions that are used as a basis for implementing laws or laws that will be upheld it is no longer in accordance with the times and demands for a sense of justice, or if the law does not regulate, the judge must explore, follow and understand the values law and a sense of justice that lives in society. Through law enforcement in the court, it is expected that judges' decisions, in addition to realizing order and legal certainty, must also realize laws that fulfil a sense of justice.

But the fact is that happening in the field, not all judges carry out their profession in accordance with the code of ethics of the judge's profession that is regulated in the Joint Decree of the Chief Justice of the Republic of Indonesia and the Chairperson of the Republic of Indonesia Judicial Commission Number: 047 / KMA / SKB / IV / 2009 and 02 / SKB / P. KY / IV / 2009 concerning the Code of Ethics and Conduct of Judges. Sometimes there is a state of failure to achieve legal goals namely justice and legal certainty called the Miscarriage of Justice.

A miscarriage of justice, also known as a failure of justice, occurs when a person is convicted and punished for a crime that he or she did not commit. "Miscarriage of justice" is sometimes used to describe any wrongful conviction, even when the defendant may be guilty, for example in reference to a conviction reached as the result of an unfair or disputed trial. A miscarriage of justice has been defined as "a grossly unfair outcome in a judicial proceeding, as when a defendant is convicted despite a lack of evidence on an essential element of the crime".

Miscarriage of justice occurs when judges have obstacles in the process of realizing the nine, internal obstacles that come from within themselves. The meaning of judging means giving "fair" or justice. Therefore the Judge's decision was given an executorial plea "For the sake of justice based on the Almighty God". Without these steps, the judge's decision does not have a valid legal force, so it will not be enforceable. Decisions of judges that cannot be implemented (non-executable) or decisions that do not fulfil a sense of justice are tantamount to being of no benefit to justice seekers, because the objectives expected by justice seekers in court proceedings other than that the law can be upheld and in that way justice can be realized, but if for certain reasons the decision cannot be implemented, then there will be no benefit or use for the disputing parties.

If miscarriage of justice occurs at the level of investigation, then we can take pretrial legal remedies. However, if it happens when we have a decision that has legal force we can still take extraordinary legal remedies called Review which is regulated in Articles 263, 264, 265, 266, 267, 268 Criminal Procedure Code. Maybe if it is examined easily because all that remains is to make a review effort, but it should be better than miscarriage of justice does not happen. Judges should do their job in earnest to avoid miscarriage of justice.

Each Court Chairperson must make every effort to ensure that the Judges in their environment comply with the Judge's Code of Conduct. Violations of the Judge's Code of Conduct may be subject to sanctions. In determining sanctions that are appropriate to be 
imposed, factors must be considered related to the violation, namely the background, the level of seriousness, and the consequences of the violation against the judiciary or other parties. Judges who are alleged to have violated this regulation were examined by the Supreme Court of the Republic of Indonesia and or the Judicial Commission of the Republic of Indonesia. The Supreme Court of the Republic of Indonesia or the Judicial Commission of the Republic of Indonesia shall submit the results of the decision on the results of the examination to the Chairman of the Supreme Court of the Republic of Indonesia. Judges who are proposed to be subject to sanctions on termination and dismissal by the Supreme Court of the Republic of Indonesia or the Judicial Commission of the Republic of Indonesia are allowed to defend themselves in the Honorary Council of Judges.

\section{CONCLUSION}

Justice is something aspired by the people of Indonesia. Judges are the most important element in realizing justice that is highly aspired. Judges as representatives of God who hold to the "For the sake of justice based on the Almighty God" develop a difficult task. Many miscarriage of justice occurs in the community. Judges as a profession that has a higher degree must hold on to professional ethics to avoid miscarriage of justice.

\section{REFERENCE}

Attamimi, A. H. S. (1992). Teori perundang-undangan Indonesia”. A journal from speech ceremony at Law faculty of UI. Jakarta. Jakarta: Universitas Indonesia Press.

Cooley, C. M., \& Turvey, B. E. (2014). Miscarriages of Justice: Prevention and Management. Miscarriages of Justice: Actual Innocence, Forensic Evidence, and the Law. Elsevier Inc. https://doi.org/10.1016/B978-0-12-411558-3.00013-7

Elks, L. (2008). Righting Miscarriages of Justice? Ten years of the Criminal Cases Review Commission. London: A Justice Publication.

Gill, P. (2016). Analysis and implications of the miscarriages of justice of Amanda Knox and Raffaele Sollecito. Forensic Science International: Genetics, 23, 9-18. https://doi.org/10.1016/ j.fsigen.2016.02.015

Greenwood, H., \& Eady, D. (2019). Re-evaluating post-conviction disclosure: A case for 'better late than never.' International Journal of Law, Crime and Justice, 59(February), 0-1. https:// doi.org/10.1016/j.ijlcj.2019.05.001

Lee, Y. H. (2020). How Police Policies and Practices Impact Successful Crime Investigation: Factors That Enable Police Departments to "Clear" Crimes. Justice System Journal, 41(1), 37-62. https://doi.org/10.1080/0098261X.2020.1719246

Mertokusumo, S. (2018). Mengenal hukum: Suatu Pengantar. Jakarta: Cahaya Atma.

Nobles, R., \& Schiff, D. (1995). Miscarriages of Justice: A Systems Approach. The Modern Law Review, 58(3), 299-320. https://doi.org/10.1111/j.1468-2230.1995.tb02012.x 